\title{
New functionalism: rejuvenating historical and cultural heritage through urban revival
}

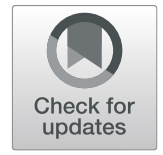

\author{
Jijiao Zhang
}

Received: 16 June 2019 / Accepted: 2 October 2019 / Published online: 29 October 2019

(C) The Author(s). 2019 Open Access This article is distributed under the terms of the Creative Commons Attribution 4.0 International License (http://creativecommons.org/licenses/by/4.0/), which permits unrestricted use, distribution, and reproduction in any medium, provided you give appropriate credit to the original author(s) and the source, provide a link to the Creative Commons license, and indicate if changes were made.

\begin{abstract}
The better protection and utilization of historical and cultural heritage sites, objects, and practices (especially intangible aspects of cultural heritage) based on anthropological research can work in the field of urban planning and design, an applied field with interdisciplinary cooperation, thus bringing new vitality to urban development. Additionally, the relationship between historical and cultural heritage and urban revival is not only binary opposition, but also coexistence and connection. Thus, this article does not highlight the dichotomy of tradition vs. modernity. After a critique of the inherited "view of cultural conservatism", based on Malinowski's classic and static "cultural functionalism", Fei Xiaotong's idea of "cultural development and utilization", Li Peilin's "continuous spectrum" theory and the "Wirth-Redfield" model, this paper puts forward a classic and dynamic theory of "new functionalism" that analyzes the relationship between historical and cultural heritage and urban revival through the new value of historical and cultural heritage in urban revival. The comparative cases focus on four domestic and foreign cities_— the City of York, England; Kyoto, Japan; Dali in Yunnan, China; and Haikou in Hainan, China_ and show that the protection and utilization of historical and cultural heritage is one of the core issues of urban revival. In this light, tangible historical and cultural heritage is the "body" and intangible heritage is the "soul" of urban areas. It is important to integrate the traditional "body" with the innovative "soul". In urban revival, only when we protect and use sites of historical and cultural heritage well, and rejuvenate them for driving urban development, will the cities grow in a way that will be long-lived and healthy and along the path of sustainable development.
\end{abstract}

\footnotetext{
J. Zhang $(\bowtie)$

Department Social Research, Institute of Ethnology and Anthropology, Chinese Academy of Social Sciences, IUAES, No.6 Blg, No.27, Zhongguancun Nandajie Road, Beijing, Haidian District, China e-mail: zhjijiao@126.com
} 
Keywords New functionalism - Urban revival · Historical and cultural heritage · Sustainable development

\section{Introduction}

Since the 1980s, cities all over China have been competing for development and quite a few historical and cultural heritage sites have been damaged or even lost, thereby accelerating the decline of ancient city districts. Some city governments suggested that an "ancient city" is an awful mess left by the past and a heavy burden of cities' progress. They argued for the "eradication of the old for the new" and to "cut the Gordian knot with a sharp knife". As a result, in these cities, nearly all old houses were demolished to make urban planning easier and to speed up construction projects, with the primary historical and cultural remains, original characteristics, and local styles all wiped out in a blink, causing the history to be disastrously cut off.

Entering the twenty-first century, the available urban land has become increasingly rare, and city governments began to regard sites of historical and cultural heritage as a treasure to be further tapped and utilized. Such sites include the Three Lanes and Seven Alleys in Fuzhou, Fujian; East and West Lane in Guilin, Guangxi; and Arcaded Streets in Haikou, Hainan. In response, renovations of historical and cultural streets, ancient neighborhood blocks, and old commercial streets have thrived throughout the country, marking a shift in China's urban development from quantity to quality.

In 2003, the United Nations Educational, Scientific and Cultural Organization (UNESCO) passed "The Convention for the Safeguarding of Intangible Cultural Heritage", which intends to strengthen the information exchange and cooperation among governments, social organizations and ordinary people in order to protect and utilize intangible cultural heritage. Different scholars focus on different fields. The urban planner is primarily concerned with the planning and design of cities; the economist pays attention to urban economic growth; the anthropologist and the ethnologist are adept at researching national traditional culture. Overall, we need to undertake the mission of combining historical and cultural heritage with urban development together through multiple disciplines. ${ }^{1}$

In 2016, The author headed a project team aiming at a thousand-year-old city, and created the "Nine-in-One Analysis Method" that included politics, education, cultural relics, ancestral temple culture, religion, commerce, arts, folklore, and ecology, thus attempting to tap into and use aspects of its historical and cultural heritage in an all-around and thorough way. After eight years of research (Huang and Zhang 2013; Zhang 2016a, b, c, d; Zhang and Huang 2015), I feel deeply that not

\footnotetext{
${ }^{1}$ See Zhang 2015a, 2015b, 2015c, "Enterprise Anthropology: Discipline System Construction, Current Development Situation and Future Prospect," Hangzhou: Journal of Hangzhou Normal University (Humanities and Social Sciences), No.4, pp. 106-118.
} 
enough effort has been applied to the study of the new value of historical and cultural heritage in urban renewal, and that it needs to be strengthened in Chinese academia. Given the complexity and diversity of cities as well as the need to develop local theories, I hope that all scholars, whether they are from the disciplines of sociology, anthropology, ethnology, folklore, or urban planning and design, should actively take part in the reconstruction project of historical and cultural streets, ancient urban districts, and old business streets in cities across China, to conduct interdisciplinary research and comprehensive analysis.

\section{Literature review}

In the academic circle of urban development research in China, the discussion on urban revival has been going on for more than 30 years, mainly initiated and led by urban planning scholars. In the 1980s, Chen Zhanxiang pointed out that urban renewal is a process of "metabolism in urban development". ${ }^{2}$ In the 1990s, Wu Liangyong expounded the "organic renewal" theory from the perspective of "urban protection and development". 3 In recent years, a typical example of China's exploration of urban revival from the perspective of urban planning was the Shanghai World Expo in 2010. In the Urban Best Practice Area, one of the four major themes was Protection and Utilization of Historical Heritage. ${ }^{4}$ For example, the Pavilion of Barcelona presented a model of urban design combining the ancient with the modern-ancient city districts built in the Middle Ages and new urban districts with emerging industries coexisted harmoniously. The subject of the Pavilion of Suzhou was "the protection and reconstruction of ancient cities in Suzhou", condensing Suzhou's 2500-year historical and cultural heritage with modern civilization, and demonstrating the fascinating ancient and modern style of Suzhou.

Some terms such as urban renewal, urban revival, urban revitalization, and ancient city protection have been raised at home and abroad. Although their

\footnotetext{
${ }^{2}$ See Chen 1983, “City Design,” Beijing: Urban Planning Studies, No.1, pp. 4-19. Chen 1989. "My Impression on Urban Planning in America,” Beijing: Urban Planning Review, No.2, pp. 46-48.

${ }^{3}$ See Wu 1991a, 1991b, 1991c, "From 'Organic Renewal' to 'Organic Order'- The Improvement Approaches of the Beijing Residential Area of Old-block," Beijing: Architectural Journal, No.2, pp. 713. Wu 1991a, 1991b, 1991c, "Perspective on the Structure of Chinese Urban Planning System- Speaking from the Progress and Perplexity in the Contemporary Urban Planning in the West," Beijing: Urban Planning Review, No.5, pp. 3-12. Wu 1991a, 1991b, 1991c, "The Theoretical Problems of Juer Hutong Test- The Renovation of Dilapidated Houses and Old Residential District of Beijing," Beijing: Architectural Journal, No.12, pp. 2-12. Wu 1993, “Abstract inheritance and critical inheritance- The Conservation and Development of Historical Spots and the Creation of New Buildings," Beijing: Architectural Journal, No.10, pp. 21-24.

${ }^{4}$ The Urban Best Practice Area (UBPA) in Shanghai World Expo 2010 was divided into four fields: Livable Cities, Sustainable Urbanization, Protection and Utilization of Historical Heritages and Technological Innovation in Built Environment, which stretch over 150,000 square meters (15 ha) and enjoy the name of "Exhibition-within-Exhibition" with 50 outstanding city cases across the world.
} 
connotations differ, ${ }^{5}$ their target is essentially the same, that is, they all attempt to revitalize and energize the modern city through rebuilding old cities and restoring their vitality and energy.

Leading by the urban planning savants, experts from various fields, including urban economics, archaeology, sociology, anthropology, ethnology, folklore, and history, are all taking an active part in the project of urban revival and discussing the revival of urban construction from different perspectives. In addition, they not only attend academic discussions on related topics, proposing various practical and academic ideas and recommendations, but also share in various urban renewal planning and construction projects in all parts of the country. Anthropologists have also been major players. For example, in the study of urban revival, some anthropologists have analyzed the relationship between historical \& cultural heritage and urban transformation based on years of field work and research on time-honored brands and old city blocks. ${ }^{6}$

\section{The analytical framework}

This paper puts forward a classic and dynamic theory of "new functionalism" to analyze the relationship between historical and cultural heritage and urban revival through the new function of historical and cultural heritage in urban revival, to explore how to tap into and better use sites of historical and cultural heritage (especially intangible cultural heritage) and thus rejuvenate them.

There were some studies among western scholars about the function of culture which was further developed by Chinese scholar to apply it to Chinese modern development. In his famous book A Scientific Theory of Culture, Bronislaw Kaspar Malinowski, a social anthropologist of the British classical

\footnotetext{
${ }^{5}$ For example: "Preservation and Planning of the Historic Block" proposed by Ruan Yisan, "the Protection of Ancient City" by Wu Liangyong, "Urban Revival" by Wu Chen, "Urban Regeneration" by Zhang Pingyu.See Ruan 2000, "Preservation and Planning of the Historic Block," Beijing: Urban Planning Forum, No.2, pp. 46-50. Wu 2005a, 2005b, 2005c, "The Theoretical Analysis of "Urban Revival'- The future of city is the future of the Earth -Kenneth Powell," Beijing: Beijing City Planning and Construction Review, No.1, pp. 140-143. Wu 2005a, 2005b, 2005c, "Studies on the Protection of Beijing Ancient City (Part 1)," Beijing: Beijing City Planning and Construction Review, No.1, pp. 2028. And "Studies on the Protection of Beijing Ancient City (Part 2)," Beijing: Beijing City Planning and Construction Review, No.2, pp. 65-72. Zhang 2004a, 2004b, "Urban Regeneration: Theory and Practice in China's New Urbanization," Beijing: City Planning Review, (4) pp. 25-30. Zhang 2004a, 2004b, "Towards Three-way Partnership in Urban Regeneration: The Western Experience and Implications to Chinese Cities," Beijing: Urban Studies, Volume 11, No.4, pp. 26-32.

${ }^{6}$ For example, Development Report of China Old Brand Enterprises No.1 (2011), edited by Zhang Jijiao, Ding Huimin, and Huang Zhongcai; Old Brand Enterprises- Case studies and development report NO.2(2013-2014), edited by Zhang Jijiao, and Liu Weihua; Old Brand Enterprises- Case studies and development report NO.3(2015-2016), edited by Zhang Jijiao, and Liu Weihua; Old Brand Enterprises- Case studies and development report NO.4(2016-2017), edited by Zhang Jijiao, and Liu Weihua; Old Brand Enterprises- Case studies and development report NO.5(2017-2018), edited by Zhang Jijiao, and Liu Weihua
} 
functional school, pointed out that the essence of culture is not revealed in its superficial features, but in its functions which are the role of culture itself in meeting human needs. However, Malinowski's "cultural functionalism" refers to the original function of culture in pre-modern society and does not indicate that of modern transformation, so it is a classical and static "theory of function”. Fei Xiaotong, who was Malinowski's student in China, pointed out that traditional national culture is a resource that can be exploited and utilized. Fei Xiaotong's idea of "cultural development and utilization" obviously has a taste of functionalism, and it implied there may be some new functions of culture to be developed and utilized.

"Cultural functionalism" (1944) put forward by Malinowski more than seventy years ago is a classical and static "theory of function", while the idea of "cultural development and utilization" (2001) put forward by Fei more than ten years ago is a neoclassical view based on China's specific conditions and goes further than the former theory. However, this view still needs to be further improved. Based on the theory of "cultural functionalism" and "cultural development and utilization", this paper wants to set up a theory of classic, dynamic "new functionalism", aiming at exploring the new functions of historical \& cultural heritage sites and their relationship with the urban revival.

If we want to make up a fresh research paradigm_- "new functionalism" to deal with the topic of inheritance and development of historical \& cultural heritage, in this paper specifically, the relation between historical \& cultural heritage and urban revival, we should clarify in the first place the relation between tradition and modernization. In this regard, we have abandoned the "dichotomy" analytical framework. The idea of "dichotomy" has generally been adopted as a basic analytical framework or classic models since the earlier studies of sociology and anthropology: the opposition between status society and contract society by H. Maine (1861), the opposition between the communal society and the associational society by F. Tonnies (1887), the opposition between mechanical solidarity and organic solidarity by E. Durkheim (1893), the opposition between pre-modern society and modern society, between the formal rationality and substantial rationality, and between traditional authority and legal authority by M. Weber (1922), the opposition between "primitive or folk society" and "modern urbanized society" by R. Redfield (1947), the opposition between particular value and universal value by T. Parsons (1951). In these models that embody the idea of dichotomy, their basic viewpoints are: firstly, the trend of development from traditional society to modern society is irresistible and inevitable. All kinds of cultural heritages in the world are at two poles, either traditional one or modern one; and secondly, that, in essence, the traditional and the modern are antagonistic. In the modern economy and society, human being should shed its tradition, or else they may be caught in a variety of contradictions and conflictions.

As Li Peilin (2002) has pointed out, in fact, there is a "continuous spectrum" of the real world between the binary oppositions we have been accustomed to, which cannot be fully explained by the idealized binary oppositions analysis framework 
(such as rural-urban, tradition-modernity, etc.). ${ }^{7}$ Sociologists and anthropologists put forward the "coexistence" model, economists and political scientists put forward the "articulation" model to refute the simple dichotomy of the "opposition-assimilation" model. Louis Wirth (1938) proposed the concept of "urbanism", and Robert Redfield (1947) adapted his idea of a "folk-urban continuum" to Wirth's formulation. Redfield (1956) argued that culture could be divided into the "great tradition", which is centred on the city and reflects the cultural and political elites' culture, and the "little tradition" of folk culture, which is rooted outside the city among the rural community. Their research orientation is subsequently known as the "Wirth-Redfield" model. A previous discussion on the economic-cultural types of Chinese minority's rural-urban migration as being from "original ecology" to "market-oriented" supported the same hypothesis. ${ }^{8}$ We think the relationship between historical \& cultural heritage and urban revival, which is a type that embodies tradition-modernization relationship, is not just binary, but coexistence and connection, etc. We had better abandon the analytical paradigm of "opposition-assimilation" and adopt instead a multianalysis one. Therefore, the relationship between historical \& cultural heritage and urban revival is not so much a completely binary one as coexistent, connection and other "continuous spectrum" phenomena. Further, historical \& cultural heritage may spark new value or functional transformation in urban revival.

Therefore, based on "cultural functionalism" theory, view of "cultural development and utilization", "continuous spectrum" theory and the "Wirth-Redfield" model, this paper attempts to make up a theory of "new functionalism", its goal is to explore the new functions of historical \& cultural heritage sites on the one hand and their relationship with the urban revival on the other, to address the topic of the traditional-modern transformation of China dynamically.

\section{Case studies of ancient cities at home and abroad}

In the last decade, I visited thirty-three countries and regions all over the world, ranging from Asia, Europe, and America to Africa to explore the relationship between urban revival and traditional historical and cultural heritage, here, I just take four ancient cities as examples.

\section{A case study of York, England}

York, the capital of North Yorkshire, is an ancient city at the confluence of the rivers Ouse and Foss in the northeastern part of England. ${ }^{9}$ This old city is surrounded

\footnotetext{
${ }^{7}$ See Li Peilin, Tremendous Changes: The End of Villages-A Study of Villages in the Center of Guangzhou City, Social Sciences in China,2002(01):168-179 + 209.

${ }^{8}$ This refers to the paper- The economic-cultural patterns of ethnic minority migrants in the cities of China, published in Malaysian Journal of Chinese Studies, Vol. 3, No. 2, 2014.

${ }^{9}$ I visited the ancient city of York in 2010. Strolling through the ancient Roman walls, I could see various streets scenes and buildings from different periods as well as visitors from all around the world.
} 
by ancient Roman walls that were mostly reconstructed in the thirteenth century, forming the current extant five kilometer long encirclement, which takes at least two hours to walk. In 1968, this district was designated as a protected zone. York Castle Museum, which was originally housed in two prison buildings, now displays street scenes, traditional houses, and the everyday life and daily activities of residents throughout the past four hundred years. ${ }^{10}$ In 1963, the University of York was founded and it has become one of the most prestigious universities in the world. In 1975, the National Railway Museum (NRM) was established. Furthermore, the JORVIK Viking Festival reenacts York's history and the charm of ancient Vikings every February. There are traditional Viking boat races and people wearing Viking helmets in the streets, all of which give a feeling of being transported back in time. Likewise, the great exhibition held in Harrogate in July is one of the biggest county fairs in the UK and all kinds of native products such as puddings, York County beef, and dogs of the local breed are available for sale in the open market everywhere. In 2007, York was named the European Tourism City of the Year. York's rich historical and cultural heritage holds wide appeal for tourists, with up to 2 million visitors a year making it the most visited city in England after London.

\section{A case study of Kyoto, Japan}

Kyoto, built-in $794 \mathrm{AD}$, is an ancient city with a history of more than 1220 years. ${ }^{11}$ As the capital city of Japan for more than one thousand years (794 AD-1868 AD), ${ }^{12}$ Kyoto has long been the center of the politics, economy, religion, education, and culture of Japan. It is estimated that $20 \%$ of Japan's national treasures remain in the city proper with its hundreds of Shinto shrines, pavilions, and Buddhist temples. For example, Kiyomizu Temple, the most famous temple in Kyoto that was built in $798 \mathrm{AD}$, was listed as a World Heritage Site by UNESCO in 1994. When one walks along the ancient streets, multifarious old stores selling traditional Japanese handcrafts such as textiles, ceramics, lacquer ware, and dyed fabrics, enter one's sight. Likewise, one sees shops featuring ikebana (traditional flower arrangements), sado (tea ceremony) and traditional foods, factors that allow visitors to appreciate Japanese culture and learn some traditional techniques on-site, such as cooking, drama, sado, ikebana, silk, ceramics, papermaking, temple outfits and the like. There are festival activities almost every day and the three most popular are the

\footnotetext{
${ }^{10}$ Those aspects of historic and cultural heritage, including local customs and folk lifestyle and other kinds of intangible factors of cultural heritage, originated mainly from 1580 to 1980, especially in Victorian and Edwardian eras.

${ }^{11}$ I visited Kyoto three times, in 2003, 2004, 2014. On my third visit I started to really focus on the influence of historic and cultural heritage on modern tourism and commercial activities.

${ }^{12}$ The capital city of Japan was moved to Tokyo from Kyoto in 1868.
} 
Aoi Festival, ${ }^{13}$ the Gion Festival, ${ }^{14}$ and the Jidai Festival. ${ }^{15}$ The activities in the Gion Festival, for example, take place annually in Kyoto's Gion district, which is the largest geisha district in Kyoto, developed from the road in front of Yasaka Jinja Shrine. Now, it has grown into an ageless busy street where visitors can find stores selling buns, incense, Japanese style clothing and costumes as well as some ancient restaurants and teahouses which have been either passed down for centuries or built in a traditional way in recent times. There are also several universities and modern education research institutions in the city. Kyoto is, by all accounts, an ancient city of culture and education and it truly lives up to its reputation.

\section{A case study of Dali, Yunnan, China}

Dali's well-preserved old town was built in 1382 AD (during the Ming Dynasty) in Yunnan. The town is encompassed by a moat and surrounded by a wall with gate towers on all four sides and turrets at four corners. The roads still maintain the chessboard-type and grid-structure they have had since the Ming and Qing Dynasties, known as "the Nine Streets and Eighteen Lanes" with five long streets running from south to north and eight lanes traveling west to east. ${ }^{16}$ There are a variety of local specialties on offer - the four treasures of study (brush pens, ink sticks, ink stones and paper), flowerpots and vases, lighting and other natural marble craft, the Bai ethnic group's batik, called bandhnu, Dengchuan dairy fan (a type of cheese product), Xiaguan Tuo tea, Jianchuan woodcarving, Dali snow pears, and so on. Beyond these, numerous festival activities take place in Dali. For example, the March Fair Festival at the foot of the Cangshan Mountains on the west edge of Dali falls between the tenth and twenty-first days the third lunar month. It is not only the grand annual festival of the Bai ethnic group, but also one of Yunnan's well-known commodity fairs. Rao Sanling (sanling refers to the three important temples in the region) takes place around the twenty-third or twenty-fourth day of the fourth lunar month in the Bai Nationality villages around Erhai Lake. This event,

\footnotetext{
${ }^{13}$ Aoi Festival, or Aoi Matsuri in Japanese, takes place on the 15th of May. It originated from a festival held by Kamo-mioya Jinja (Shimogamo Shrine) and Kamo-wakeikazuchi Jinja (Kamigamo Shrine) held in Kyoto on 15th May, 1693 and was named for mallow leaves used as decoration by parade participants and bullock carts in that time.

${ }^{14}$ Gion Festival, or Gion Matsuri in Japanese, takes place from the 16th to the 29th of July. It's one of the most famous festivals in Kyoto and is held by Yasaka Shrine. It originated at the end of ninth century when people were praying to ward off plague. At that time, they hung the god's lanterns and green curtains under the eaves with a mat unrolled, flowers used as decorations, and a screen that brightened the whole night. The next day, the festival came to its climax when people paraded through the streets, pushing a Yamaboko float made of wood covered in ancient fabrics.

${ }^{15}$ Jidai Festival, or Jidai Matsuri in Japanese, is a festival of Heian Shrine that takes place on the 22nd of October. It stages a costume show representing people of each era from Heian period (794 AD-1192 $\mathrm{AD})$ to hte Meiji restoration (beginning in $1868 \mathrm{AD}$ ) with approximately two thousand well-dressed performers who proceeding from Heian Shrine to Kyoto Goshowhile displaying the customs and folkways that have existed since Kyoto became the capital city one-thousand years ago. It presents not only the flourishing history of the ancient capital, but also the uniquely artistic charm and lively local atmosphere.

${ }^{16}$ I made a short-term investigation in Dali’s old town in June, 2014.
} 
having taken place for more than one thousand years, allows participants to greet gods and to herald spring before the busy agricultural season begins. Guan Shang Lan, also known as the "the pray-for-rain ceremony" is a three-day festival. As the name suggests (guan means to stroll) people circumambulate the Buddha at Chongsheng Temple on the first day, the image of a god in Xizhouqing Cave on the second day, and the image of a heavenly immortal at Er River Temple on the Xizhou River in Yicheng Village on the third day. ${ }^{17}$ The Torch Festival falls on the twenty-fifth day of the sixth month of the lunar calendar and is when the Bai people rest from labor and engage in a three-day revelry involving dressing in festival costumes. During the festival, people pray for the forthcoming year to bring a bumper harvest and for all domestic animals to thrive, and they hope to dispel disasters and evil spirits by arranging and igniting torches, chanting Buddhist sutras and scriptures, dancing and singing joyously, and slaughtering domestic animals.

From the above three cases (York, Kyoto, and Dali), we see that they share something in common: 1) well-preserved and well-restored ancient city walls, 2) attractive natural scenery with lakes, rivers and mountains nearby, 3) a variety of ancient temples and churches as well as historical sites, 4) native snacks, foods and restaurants with their special features, 5) various folk handicrafts and souvenirs, 6) distinctive and grand festival activities, 7) better cultural and educational resources. All in all, those city governments took full advantage of their heritage — not only the material culture of old buildings, historical and cultural monuments, or the former residences of famous people, but also the intangible cultural practices like local ancestral hall culture, religion, festivals, arts, and folk customs. This practice of utilizing intangible culture is particularly conducive to activating the development of tourism, commerce, and services in those cities.

\section{A case study of Haikou, Hainan, China}

Fucheng, a city was built in 971 AD (during the Song Dynasty) in Haikou, Hainan Province. ${ }^{18}$ This city had already been there for 1046 years before the central government set up the autonomous prefecture center. In early 2016, the Haikou government began to implement the Qiongtai Restoration Project and attempted to combine this thousand-year-old ancient city with modern reality, which not only has a bearing on renovation, but also adds further impetus to its development. Consulting the development experience of the three above-mentioned ancient cities, we proposed that utilizing the cultural heritage be of great significance in the revival of Fucheng, with tangible historical and cultural heritage acting as the "body" and

\footnotetext{
17"Rao Sanling" was listed in the first list of national intangible cultural heritage sites by the State Council.

${ }^{18}$ Fucheng, known as "Qiongzhou Fucheng" in ancient times, was the center of politics, culture and the military of Hainan. The present location of Fucheng is Fucheng Subdistrict and Binjiang Street East Gate Community under the Qiongshan District, Haikou City, Hainan Province as well as the government seat. I was educated as a high school student in Fucheng (a county of Hainan Administrative, Guangdong Province in that time) from 1980 to 1983, and I made several field investigations on "historic and cultural heritage" and talked with local cadres and ordinary people in Fucheng in 2016.
} 
intangible historical and cultural heritage as the "soul". Therefore, the traditional "body" should be integrated with the innovative "soul" helping to protect and revive the historical and cultural districts in Fucheng, regenerating Haikou as the pivot city of the ancient Maritime Silk Road, and achieving environmental improvement and industrial upgrading of this city. These factors were targeted for the revival of the traditional culture of Hainan.

For example, Fucheng, long reputed to be a "thousand-year-old ancient city", has bred hundreds of clan relations who have created a brilliant ancestral hall culture during the long march of history. Based on related reference and historical materials, while visiting the avenues and alleys in Fucheng, I have come to realize that it is the first and best choice of location for all the ancestors who arrived on Hainan Island, whether to be an official under exile, or to escape war. Their offspring built temples to worship clan ancestors and provide room and board for students to study in Xuegong Academy (Table 1).

From the above table, we can see that 18 ancestral temples existed on Fucheng's Wenzhuang Road throughout history. That means the ancestral hall culture could be regarded as one of the major aspects of the historical and cultural heritage of Fucheng, and as an essential part of the entirety of the historical and cultural heritage of Hainan. Fucheng ancestral hall culture today could serve as a critical resource for the tourism development of ancient cities in Hainan, and as a significant component in the revival of Fucheng as well.

The Flower Exchange Festival (former Incense Exchange Festival) is a traditional folk festival on the 15th day of the first lunar month in Fucheng. It is a social festival passed down for centuries and rooted and developed by local people. In recent years, at least 200,000 people have taken part in the annual exchange-offlowers activities to express their good wishes in the coming year. Nowadays, multiple athletic and recreational activities have been added to the festival activities, in addition to the exchanging of flowers.

Today, the Haikou government is working on its "two- wheel drive" policy that is building the China (Hainan) Pilot Free Trade Zone and forging the pivot city of the " $21{ }^{\text {st }}$ Century Maritime Silk Road" in the face of strategic opportunities for development powered by "The One Belt One Road Initiative". Based on field investigation and research on Haikou, we suggest that the government could turn the locally "static" manifestations of historical and cultural heritage that have accumulated for a thousand years into a "dynamic" and "living" heritage, and then organically graft it onto urban modernization by utilizing it from new heights and perspective, thus blending the ancient and the modern. All of those could be a new economic growth point in Haikou.

\section{Results and discussion}

From the above four case analyses, we are convinced that developing traditional culture is a must in the urban environment which requires the protection and promotion of local traditional culture on the verge of extinction during the process of urban revival, especially in relation to intangible aspects of cultural heritage. We view historical and cultural heritage as a unique name card for those cities, and as 
Table 1 Historical Ancestral Temples on Wenzhuang Road, Fucheng

\begin{tabular}{|c|c|c|c|}
\hline Ordinal & Name & Location & Specific Circumstance \\
\hline 1 & $\begin{array}{l}\text { Ancestral Temple of the } \\
\text { Yang Clan }\end{array}$ & $\begin{array}{l}\text { south of present Qiongshan } \\
\text { Mountain Hotel }\end{array}$ & Being demolished \\
\hline 2 & $\begin{array}{l}\text { Ancestral Temple of the } \\
\text { Ou Clan }\end{array}$ & $\begin{array}{l}\text { Behind the former Bureau } \\
\text { of Finance }\end{array}$ & Being demolished \\
\hline 3 & $\begin{array}{l}\text { Ancestral Temple of the } \\
\text { Wu Clan }\end{array}$ & $\begin{array}{l}\text { Within the Workers } \\
\text { Cultural Palace }\end{array}$ & Being demolished \\
\hline 4 & $\begin{array}{l}\text { Ancestral Temple of the } \\
\text { Ke Clan }\end{array}$ & $\begin{array}{l}\text { Within the Workers } \\
\text { Cultural Palace }\end{array}$ & Being demolished \\
\hline 5 & $\begin{array}{l}\text { Ancestral Temple of the } \\
\text { Gao Clan }\end{array}$ & $\begin{array}{l}\text { South of No.10, Shangshu } \\
\text { Zhijie Street }\end{array}$ & Being demolished \\
\hline 6 & $\begin{array}{l}\text { Ancestral Temple of the } \\
\text { Li Clan }\end{array}$ & $\begin{array}{l}\text { North of the Kindergarten } \\
\text { Office, Shangshu } \\
\text { Zhijie District }\end{array}$ & Being demolished \\
\hline 7 & $\begin{array}{l}\text { Ancestral Temple of the } \\
\text { Shi Clan }\end{array}$ & $\begin{array}{l}\text { North of the Kindergarten } \\
\text { Office, Shangshu } \\
\text { Zhijie District }\end{array}$ & Being demolished \\
\hline 8 & $\begin{array}{l}\text { Ancestral Temple of the } \\
\text { Xian Clan }\end{array}$ & North end of Datie Lane & $\begin{array}{l}\text { Moved to Feng Bao and } \\
\text { Mrs. Xian's Memorial Hall }\end{array}$ \\
\hline 9 & $\begin{array}{l}\text { Ancestral Temple of the } \\
\text { He Clan }\end{array}$ & $\begin{array}{l}\text { Left side of Qiongshan Middle } \\
\text { School }\end{array}$ & Unknown \\
\hline 10 & $\begin{array}{l}\text { Ancestral Temple of the } \\
\text { Feng Clan }\end{array}$ & Former ICBC Branch & $\begin{array}{l}\text { Moved to Feng Bao and } \\
\text { Mrs. Xian's Memorial Hall }\end{array}$ \\
\hline 11 & $\begin{array}{l}\text { Ancestral Temple of the } \\
\text { Zhou Clan }\end{array}$ & Former Food Bureau & $\begin{array}{l}\text { Covered } 7500 \text { square meters; } \\
\text { originally consisted of two jin } \\
\text { (one jin equals one row with } \\
\text { several houses) }\end{array}$ \\
\hline 12 & $\begin{array}{l}\text { Ancestral Temple of the } \\
\text { Lin Clan }\end{array}$ & $\begin{array}{l}\text { Former Qiongshan } \\
\text { Printing House }\end{array}$ & $\begin{array}{l}\text { Moved to Bigan and Matsu } \\
\text { Culture Garden }\end{array}$ \\
\hline 13 & $\begin{array}{l}\text { Ancestral Temple of the } \\
\text { Wang Clan }\end{array}$ & $\begin{array}{l}\text { Former Qiongshan Power } \\
\text { Supply Company }\end{array}$ & Under reconstruction \\
\hline 14 & $\begin{array}{l}\text { Ancestral Temple of the } \\
\text { Chen Clan }\end{array}$ & $\begin{array}{l}\text { Inside Qiongshan No. } 1 \\
\text { Primary School }\end{array}$ & Being demolished \\
\hline 15 & $\begin{array}{l}\text { Ancestral Temple of the } \\
\text { Xing Clan }\end{array}$ & $\begin{array}{l}\text { No.12, Shangshu } \\
\text { Zhijie Street }\end{array}$ & Under repair \\
\hline 16 & $\begin{array}{l}\text { Ancestral Temple of the } \\
\text { Huang Clan }\end{array}$ & $\begin{array}{l}\text { No.10, Shangshu } \\
\text { Zhijie Street }\end{array}$ & $\begin{array}{l}\text { The largest and best-preserved } \\
\text { in the city }\end{array}$ \\
\hline 17 & $\begin{array}{l}\text { Ancestral Temple of the } \\
\text { Qiu Clan }\end{array}$ & $\begin{array}{l}\text { No.10 Third Lane, } \\
\text { Jinhua Road }\end{array}$ & Well-preserved \\
\hline 18 & $\begin{array}{l}\text { Ancestral Temple of the } \\
\text { Mo Clan }\end{array}$ & $\begin{array}{l}\text { No.67 Wenzhuang Road } \\
\text { (old doorplate) }\end{array}$ & Being demolished \\
\hline
\end{tabular}

Source: Registration Form of Returning Overseas Chinese Housing Construction Subsidy in Qiongshan County (June 21, 1993); The Annals Of Fucheng(Huang Peiping, Hong Kong Jinling Publishing House, 2010, pp. 76-79); Qianlong period, Daoguang period); Qiongshan County Records (Republic of China); the surname genealogy data

both material and intangible competitive assets in urban development, reflecting the competitiveness of these cities to a certain extent. These assets could be seen as a symbol of their competitive power. The historical and cultural heritage of an 
ancient city could be seen as the city's "blood" with urban revival resembling a "blood transfusion" in the process of urban modernization both at home and abroad. Cities that want to revive require healthy blood vessels and an adequate blood supply, and only by having these can they achieve the transformation from the ancient to the modern and step onto the path of sustainable development.

\section{Conclusion}

On the surface, this paper specifically discusses the relationship between historical and cultural heritage and urban revival, but in essence it involves two topics with universal significance: the historical challenge of the relationship between tradition and modernity on the one hand, and our attitude toward authoritative theories and scholars on the other hand. These days, many scholars of urban history and culture hold the view of "cultural conservatism" to express their "political correctness" in dealing with the changes of historical and cultural heritage. In this paper, however, we emphasize that the dichotomy of tradition and modernity cannot be used to analyze the relationship between historical and cultural heritage and urban revival, because such a relationship is not simply one of binary opposition but also includes coexistence, connection and other multiple facets. And we should be well aware of our attitude toward authoritative theories and scholars. For a long time, many Chinese scholars have been accustomed to restating classical theories or interpreting the theories of academic masters, yet rarely do they express their own opinions. The theories of many domestic disciplines have been kept unchanged or even stagnated without obvious development or progress. For example, when it comes to such revered figures of anthropology as Malinowski and Fei Xiaotong, quite a few scholars consider them too highly respected to point out their limitations. Based on the theory of "cultural functionalism", "cultural development and utilization", "continuous spectrum" theory and the "Wirth-Redfield" model, the author attempts to put forward a classic and dynamic theory called "new functionalism", suggesting, namely, that historical and cultural heritage is a kind of precious heritage, and that the city is also an important part of urban economy and society. Thus, the historical and cultural heritage sites and practices should have new functions so as to have new values of existence and development in the economic and social transformation that result from urban revival.

Considering the foregoing cases, we fully appreciate a comprehensive study on traditional urban culture, and find it especially necessary to transform traditional culture into a living one during urbanization, so that it enters into the cultural DNA and life ways of modern citizens. Moreover, some development space needs to be reserved exclusively for intangible cultural heritage and we should always keep historical and cultural heritage in mind.

A new round of urbanization triggered by urban revival has recommenced in China, setting Chinese cities in a new stage, from the development of quantity to quality, and allowing them to step onto a fresh development path. The protection of and access to historical and cultural heritage are one of the innermost cores in the process of urban revival. The heritage of a place is the "source" while urban revival is the "course" in the undertaking of urban development. In the midst of 
urban revival, only when we protect and use an area's historical and cultural heritage well and rejuvenate it to drive urban development, will the cities be long-lived and healthy along the path of sustainable development.

Acknowledgements Not applicable.

\section{Authors' contributions}

The author read and approved the final manuscript.

\section{Funding}

Not applicable.

\section{Availability of data and materials}

Not applicable.

\section{Ethics approval and consent to participate}

Not applicable.

\section{Consent for publication}

Not applicable.

\section{Competing interests}

The author declares that he has no competing interests.

\section{References}

Chen, Zhanxiang. 1983. City design. Urban Planning Studies 1: 4-19.

Chen, Zhanxiang. 1989. My impressions on urban planning in America. City Planning Review 2: 46-48.

Durkheim, Émile. 1893. In The division of labour in society (French: De la division du travail social). Translated by 1997, ed. W.D. Halls. New York: Free Press.

Huang, Zhongcai, and Jijiao Zhang. 2013. The explorations of economic and social transformation: Urbanization, industrialization and inheritance of ethnic culture in China. Beijing: Intellectual Property Publishing House.

Li Peilin. 2002. Tremendous Changes: The End of Villages-A Study of Villages in the Center of Guangzhou City, Social Sciences in China 1: 168-179+209. 
Maine, Henry James Sumner. 1861. Ancient Law, Its Connection with the Early History of Society, and Its Relation to Modern Ideas (1st edition). London: John Murray. 170.

Parsons, Talcott. 1951. The social system. New York: The Free Press.

Redfield, Robert. 1947. The folk society. American Journal of Sociology 52: 293-308.

Redfield, Robert. 1956. Peasant culture and society: An anthropological approach to civilization. Chicago: Chicago University Press.

Ruan, Yisan. 2000. Preservation and planning of the historic block. Urban Planning Forum 2: 46-50.

Tonnies, F. 1887. Gemeinschaft und Gesellschaft (community and society), Leipzig: Fues's Verlag, 2nd ed. 1912. 8th ed. Leipzig: Buske, 1935 Translated and edited by Charles P. Loomis, 1957, The Michigan State University Press. 223-231.

Weber, Max. 1922. In Wirtschaft und Gesellschaft (economy and society), 2 volumes, ed. Reinhard Bendix and Max Weber. Germany: The Theory of Social and Economic Organization Translated by Parsons together with Alexander Morell Henderson in 1947; 1921-1922.

Wirth, Louis. 1938. Urbanism as a way of life, USA, Chicago. The American Journal of Sociology 44No.1 (July): 1-24.

Wu, Chen. 2005c. The theoretical analysis of "urban revival"- the future of city is the future of the earth Kenneth Powell. Beijing City Planning and Construction Review 1: 140-143.

$\mathrm{Wu}$, Liangyong. 1991a. From 'organic renewal' to 'organic order'- the improvement approaches of the Beijing residential area of old-block. Architectural Journal 2: 7-13.

$\mathrm{Wu}$, Liangyong. 1991b. Perspective on the structure of the Chinese urban planning system- speaking from the Progress and perplexity of the contemporary urban planning in the west. City Planning Review 5: 3-12.

Wu, Liangyong. 1991c. The theoretical problems of Juer hutong test- the renovation of dilapidated houses and old Residential District of Beijing. Architectural Journal 12: 2-12.

$\mathrm{Wu}$, Liangyong. 1993. Abstract inheritance and critical inheritance- the conservation and development of historical spots and the creation of new buildings. Architectural Journal 10: 21-24.

Wu, Liangyong. 2005a. Studies on the protection of Beijing Ancient City (part 1). Beijing City Planning and Construction Review 1: 20-28.

Wu, Liangyong. 2005b. Studies on the protection of Beijing Ancient City (part 2). Beijing City Planning and Construction Review 2: 65-72.

Zhang, Gengli. 2004a. Towards three-way Partnership in Urban Regeneration: The Western experience and implications to Chinese cities. Urban Development Studies 4: 26-32.

Zhang, Jijiao. 2015a. A top-down perspective: An analysis on City competitiveness, old commercial streets and time-honored brands. Journal of Guangxi University for Nationalities 2: 59-65.

Zhang, Jijiao. 2015b. Enterprise anthropology: Discipline system construction, current development situation and future Prospect. Journal of Hangzhou Normal University (Humanities and Social Sciences) 4: 106-118.

Zhang, Jijiao. 2015c. Research status, practical significance, academic value of time-honored brands- from innovative perspective of business anthropology. Innovation 1: 11-16.

Zhang, Jijiao. 2016a. Study on the long-term vitality for City development brought by time-honored brands and old commercial streets. Nationalities Forum 7: 57-75.

Zhang, Jijiao. 2016b. The cultural value of urban revival and time-honored brands: Comparison between Seoul and Beijing. Nationalities Forum 5: 55-58.

Zhang, Jijiao. 2016c. Time-honored brands and old commercial streets in the urban transformation: Comparison between Seoul and Beijing. Journal of North Minzu University 4: 17-20.

Zhang, Jijiao. 2016d. Urban revival and cultural heritage: The experience and inspiration from exploiting the value of time-honored brands on foods of Seoul, Korea. City 6: 66-69.

Zhang, Jijiao, and Zhongcai Huang. 2015. New urbanization and inheritance and development of historic heritage. Beijing: China Market Press.

Zhang, Pingyu. 2004b. Urban regeneration: Theory and practice in China's new urbanization. City Planning Review 4: 25-30.

\section{Publisher's Note}

Springer Nature remains neutral with regard to jurisdictional claims in published maps and institutional affiliations. 